\title{
STRENGTH AND DYNAMIC ANALYSIS OF A STRUCTURAL NODE LIMITING THE MULTI-OUTPUT GEAR MECHANISM
}

\author{
Mária KaČalováa ${ }^{a, *}$, Slavko Pavlenko ${ }^{b}$ \\ ${ }^{a}$ Department of Technological Systems Design, Bayerova 1, 08001 Prešov, Slovak Republic \\ ${ }^{b}$ Faculty of Manufacturing Technologies, Bayerova 1, Prešov 080 01, Slovak Republic \\ * corresponding author: maria.kacalova@tuke.sk
}

\begin{abstract}
The rapidly advancing technological development leads to designing and researching a new multi- output gear mechanism. The investigated new double-output gear mechanism has two output coaxial shafts located against the input shaft on the other side of the gearbox. The gear mechanism achieves high gear ratios. Its limiting structural node is the output stage, to which the gears belong. The problem is addressed through the analysis of the stress resistance of tooth flanks in contact and bending. The content of the paper is a comparison of analytical computations with the modal analysis on the model. We expect that new findings will be beneficial for further optimization of the gear mechanism.
\end{abstract}

KEYWORDS: double-output gear mechanism; gears; strength and dynamic analysis.

\section{INTRODUCTION}

From continuing trends of current developments, it is believed that in the 21st century, there will be a rise in production to meet higher customer demands for products. It puts a strain on the flexible response to customer requirements, and also on the construction machinery of the manufacturing technology that is related to the concept with the required technical parameters. In the development process, you can include the search for new principles of construction of the gear mechanism. It has been developed with efforts to increase the carrying capacity and lifespan, with the possibility of creating a gear mechanism with a wide range of gear ratios with one or multiple outputs. The nearest area of the current state of the principles of comparability solutions and possibilities of application in production engineering have been chosen high-precision gears. The term "high-precision gears" or "gears of high accuracy" have been invented by producers of their respective products. The producer declared a high accuracy of the transfer of their characteristic precision. In this regard, it should be noted that this kind of reducers has a relatively short history of development and implementation. Currently, the world's leading companies producing these reducers include Japanese company Tein Seiki, Sumitomo Cyclo and Harmonic Drive. High-precision gears are predestined for applications in machinery and equipment, which require virtually zero clearance, high positioning accuracy and repeatability of accomplishing its high stiffness with the requirement of a higher gear ratio.

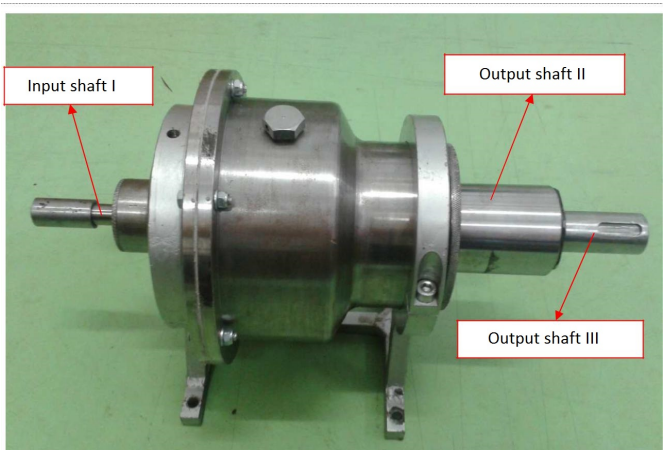

Figure 1. Functional model of double-output gear mechanism

\section{Materials AND MEthods}

The Department of Technical Systems design on Faculty of Manufacturing Technologies in Prešov of the Technical University in Košice has designed the highprecision gears multi-output transmission gear mechanism shown in Figure 1, Designed from an existing utility model number 3937 Harmonic double-output gear mechanism, authors: Ing. Jozef Halko, PhD., prof. Ing. Vladimír Klimo, CSc. The gear mechanism achieves small and large ratios at the same time. The limiting output stage is a hollow shaft with an internal gearing at the end that needs an investigation from the strength and dynamics point of view.

Figure 2 shows the basic scheme of a double-output gear mechanism that has two output coaxial shafts II and III located against the input shaft I on the other side of the gearbox. The output stage of the double-output gear mechanism shown in Figure 2 under number II was researched. 


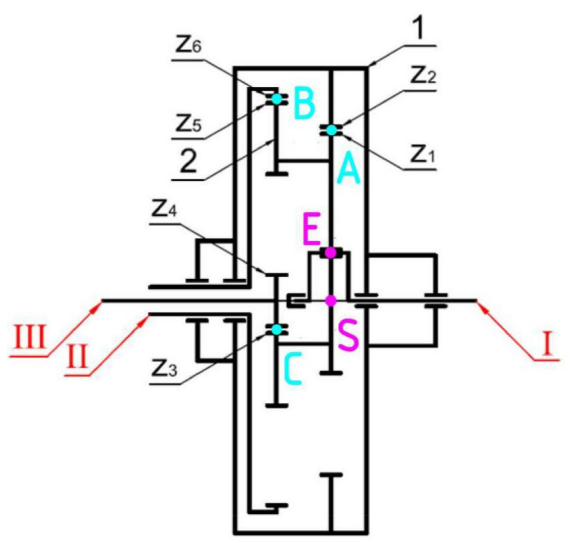

FiguRE 2. Principal scheme of double-output gear mechanism: I - input shaft, II - output shaft, III output shaft, $\mathrm{S}$ - central axis, E - eccentricity, $\mathrm{z}_{1}-\mathrm{z}_{6}-$ numbers of teeth, 1 - frame, 2 - gear wheel

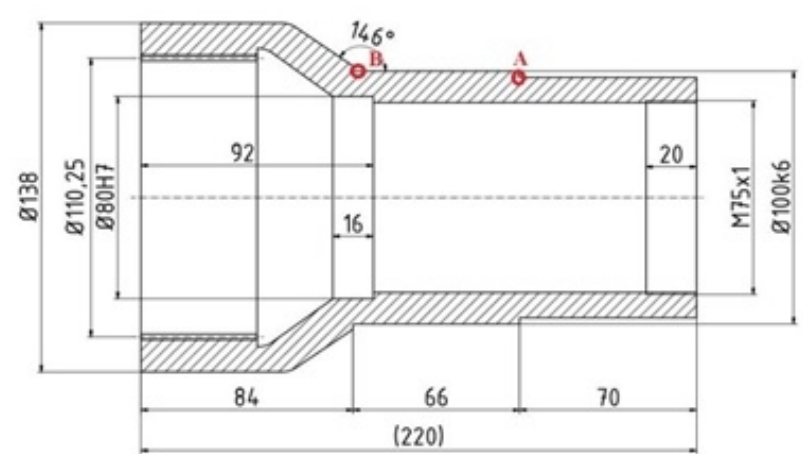

FiguRE 3. Output stage of gear mechanism

\begin{tabular}{lccccc}
\hline & Diameter & $\begin{array}{c}\text { Hertz pressure } \\
\text { under ideal load }\end{array}$ & $\begin{array}{c}\text { Coefficient of the } \\
\text { additional forces }\end{array}$ & $\begin{array}{c}\text { Hertz allowable } \\
\text { pressure }\end{array}$ & $\begin{array}{c}\text { Hertz stress } \\
\text { in contact }\end{array}$ \\
\cline { 2 - 6 } & $d[\mathrm{~mm}]$ & $\sigma_{\mathrm{HO}}[\mathrm{MPa}]$ & $k_{\mathrm{H}}[-]$ & $\sigma_{\mathrm{hp}}[\mathrm{MPa}]$ & $\sigma_{\mathrm{H}}[\mathrm{MPa}]$ \\
\hline Gear & 101 & 180.41 & 2.486 & 281.15 & 284.46 \\
Pinion & 101 & 99.52 & 2.486 & 281.15 & 156.91 \\
\hline
\end{tabular}

TABLE 1. The results of strength analysis for fatigue in contact.

\begin{tabular}{lccccc}
\hline & $\begin{array}{c}\text { Circumferential force } \\
\text { corresponding to the } \\
\text { first degree of load }\end{array}$ & $\begin{array}{c}\text { Allowable } \\
\text { stress } \\
\text { in contact }\end{array}$ & $\begin{array}{c}\text { Maximum } \\
\text { load }\end{array}$ & $\begin{array}{c}\text { Coefficient } \\
\text { of the dynamic } \\
\text { external forces }\end{array}$ & $\begin{array}{c}\text { Hertz } \\
\text { stress } \\
\text { in contact }\end{array}$ \\
\cline { 2 - 6 } & $F_{\mathrm{t} 1[\mathrm{~N}]}$ & $\sigma_{\mathrm{HP}, \max }[\mathrm{MPa}]$ & $\sigma_{\mathrm{H}, \max }[\mathrm{MPa}]$ & $k_{\mathrm{AS}}[-]$ & $\sigma_{\mathrm{H}}[\mathrm{MPa}]$ \\
\hline Gear & 3376.7 & 620 & 348.39 & 1.5 & 284.46 \\
Pinion & 419.69 & 620 & 192.17 & 1.5 & 156.91 \\
\hline
\end{tabular}

TABLE 2. The results of strength analysis for disposable load in contact.

\subsection{Strength AnALYSis OF THE OUTPUT STAGE}

The output stage shown in Figure 3 is the most stressed and loaded with high torques. It is a hollow shaft with an internal gearing at the end. This internal gearing has been analysed by a strength analysis.

Strength analysis was performed on the gear:

- fatigue in contact Table 1

- disposable load in contact Table 2

- bending fatigue Table 3 .

- disposable retraced bending Table 4.

Strength calculations of the investigated gear were carried out according to the standard STN 014686 based on the basic input parameters for a given gear.

\subsection{DYNAMIC ANALYSIS OF THE OUTPUT STAGE}

The output stage of the gear mechanism shown in Figure 3 was analysed by a dynamic analysis for fatigue.
The following condition have to be fulfilled:

$$
k_{\mathrm{C}}<k,
$$

where $k_{\mathrm{c}}$ is the minimum dynamic safety and $k$ is the overall safety margin.

While the minimum dynamic safety for a less accurate calculation without any experimental verification is $k_{\mathrm{c}}=1.5-1.8$.

The overall safety margin is calculated as:

$$
k=\frac{k_{\sigma} \cdot k_{\tau}}{\sqrt{k_{\sigma}^{2} \cdot k_{\tau}^{2}}},
$$

where $k_{\tau}$ is a safety against a fatigue failure under a torsion loading and $k_{\sigma}$ is a safety against a fatigue failure under a bending stress.

\subsection{MODAL ANALYSIS OF THE OUTPUT STAGE}

A modal analysis method can solve many technical problems encountered in the design, manufacture and operation of mechanical systems or parts. In this 


\begin{tabular}{lcccc}
\hline & $\begin{array}{c}\text { Coefficient of } \\
\text { the additional } \\
\text { load }\end{array}$ & $\begin{array}{c}\text { Bending stresses } \\
\text { in the dangerous } \\
\text { section of dedendum }\end{array}$ & $\begin{array}{c}\text { Permissible } \\
\text { bending } \\
\text { stress }\end{array}$ & $\begin{array}{c}\text { Safety factor against } \\
\text { fatigue fracture } \\
\text { in the dedendum }\end{array}$ \\
\cline { 2 - 5 } & $k_{\mathrm{F}}[-]$ & $\sigma_{\mathrm{F}}[\mathrm{MPa}]$ & $\sigma_{\mathrm{FP}}[\mathrm{MPa}]$ & $S_{\mathrm{F}, \min }[-]$ \\
\hline Gear & 2.465 & 260.71 & 254.29 & 1.4 \\
Pinion & 2.465 & 33.74 & 254.29 & 1.4 \\
\hline
\end{tabular}

TABLE 3. The results of strength analysis for bending fatigue.

\begin{tabular}{lccc}
\hline & $\begin{array}{c}\text { The biggest local bending } \\
\text { stresses in the dedendum }\end{array}$ & $\begin{array}{c}\text { Permissible bending stress } \\
\text { at maximum load }\end{array}$ & $\begin{array}{c}\text { Bending stress } \\
\text { at maximum load }\end{array}$ \\
\cline { 2 - 4 } & $\sigma_{\mathrm{F}, \max }[\mathrm{MPa}]$ & $\sigma_{\mathrm{FP}, \max }[\mathrm{MPa}]$ & $\sigma_{\mathrm{F}, \mathrm{St}}[\mathrm{MPa}]$ \\
\hline Gear & 391.07 & 712 & 890 \\
Pinion & 50.06 & 712 & 890 \\
\hline
\end{tabular}

TABLE 4. The results of strength analysis for disposable retracted bending.
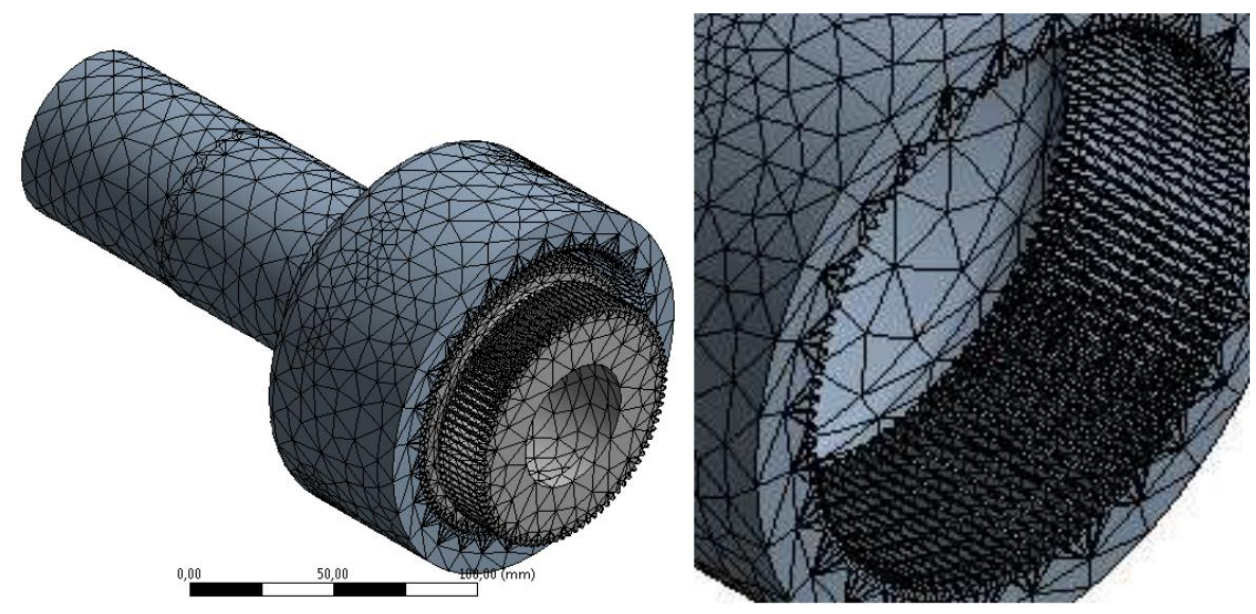

FiguRE 4. Finite element mesh created on the model of the output stage.

\begin{tabular}{lrr}
\hline & \multicolumn{1}{c}{$\mathrm{A}$} & \multicolumn{1}{c}{$\mathrm{B}$} \\
\hline$k_{\sigma}$ & 5.23 & 9.79 \\
$k_{\tau}$ & 21.25 & 23.34 \\
$k$ & 5.08 & 9.03 \\
\hline
\end{tabular}

TABLE 5. The results of dynamic analysis of output stage.

work the Finite Element Method (FEM), which is a frequently used numerical method, was used. The analysed output stage of the double-output gear mechanism has been created in ANSYS Workbench 14.5. The calculation model was created with the defined exact geometry, high-quality finite element mesh model and a corresponding load. Figure 4 shows the finite element mesh of the output stage of the doubleoutput gear mechanism, and the Figures 5 and 6 show the stress in the meshing of the mating teeth. On the wheel, the maximum tension value $335.66 \mathrm{MPa}$ is reached at the point of contact with the teeth and the maximum tension value reached on the pinion is 187.50 MPa.

\section{DisCUSSION}

Using a finite element method on the output stage of the double-output gear mechanism, it has been found out that the greatest stress $335.66 \mathrm{MPa}$ is on the wheel gear, opposed to $187.50 \mathrm{~Pa}$ on the pinion. The analytical solution values of the tension calculated for the wheel and pinion are 284.46 MPa and 156.91 MPa respectively. The verification of the results of the calculated values of the tension differs from the values generated by the ANSYS analysis. Probably due to rounding of the results and the distribution of the finite element mesh. The finite element method (FEA) is widely used to optimize the gearing. Workplaces, such as Collage of Information and Control Engineering in China, Department of Mechanical Engineering, Curtin University, Bentle \& Western Australia, also use this method in their work. In a similar way, by comparing calculated and generated values, the School of Mechanical Engineering, Department of Design and Automation, University, Vellore, Tamil Nadu, India followed these principles. They used this experiment to analyse the gear system for the turboshaft aero engine reduction gearbox. 

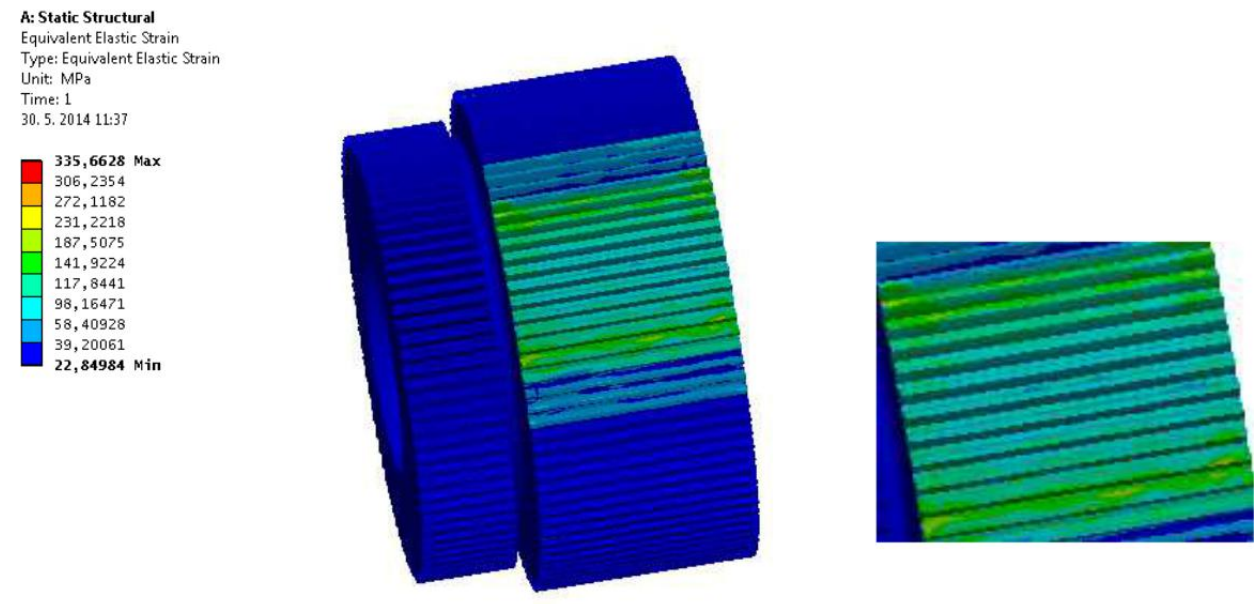

FiguRE 5. Analysis of pinion teeth at contact.

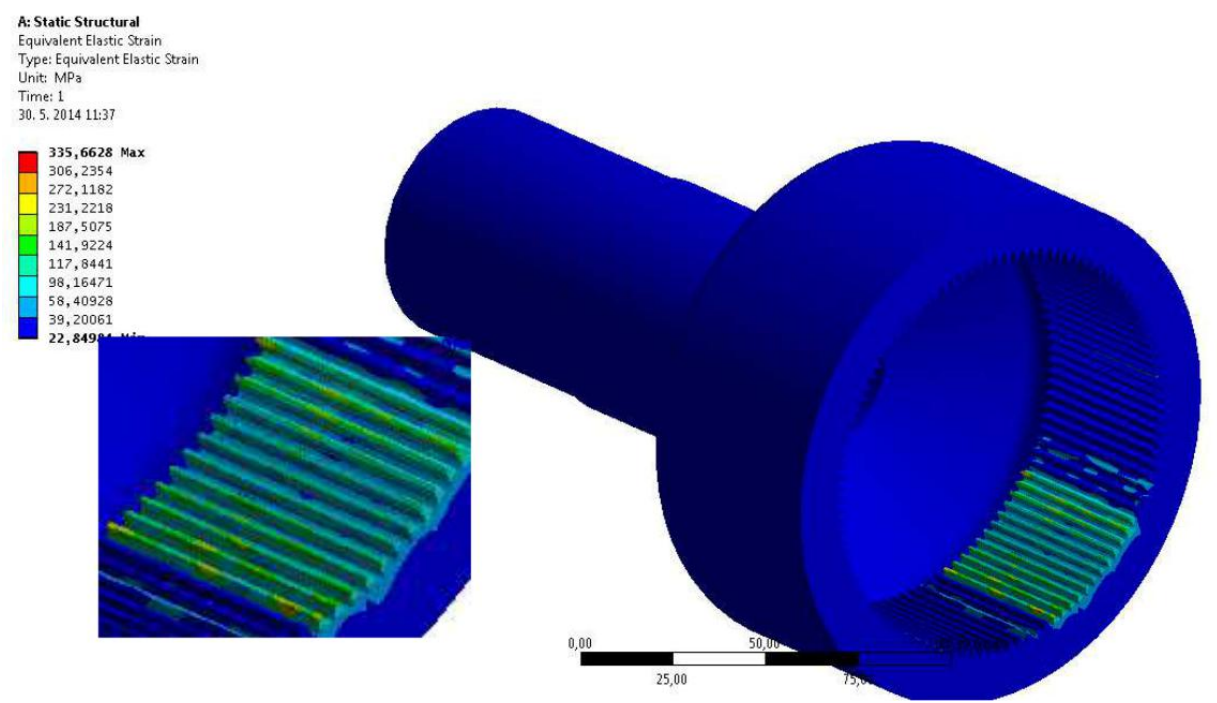

Figure 6. Analysis of the gear at the point of contact of teeth.

\section{Conlusion}

The main task of this paper was to find the limit states of the output stage of the double-output gear mechanism. Based on these results, we can continue to optimize the entire double-output gear mechanism. The authors will continue their work in research, development, testing and diagnosis of these newly developed transmission mechanisms at the Department of Technical Systems Design, Faculty of Manufacturing Technologies. We can say that the Finite element method (FEA) is a reliable method for optimizing individual parts of the gear mechanism as well as other components of the manufacturing technologies.

\section{REFERENCES}

[1] J. Halko, V. Klimo. Dvojstupňový viacvytupový harmonický prevod, Úžitkový vzor zaregistrovaný Úradom priemyselného vlastníctva SR č. 3937, 2004.

[2] J. Halko, I. Vojtko. Simulácia prevodovky vo virtuálnom prostredí. Acta Mechanica Slovaca, roc. 11, c. 4-A, s. 89-94, ISSN 1335-2393, 2007.
[3] J. Paško, S. Pavlenko. J. Halko. Conditions for toothing in two-stage multi-output transmissions. In: Scientific Bulletin. Vol. 20, serie C (2006), p. 315-320. ISSN 1224-3264, 2006.

[4] J. Paško, J.Halko. S. Pavlenko. Možné viarianty riešenia dvojstupňových prevodov s vnútorným obežným kolesom, Possible solution variants of two-degree gears with inner impeller, In: Sborník medzinárodní 46. Conference kateder části a mechanizmu stroju - Liberec: TU, 2005 P. 269-273. IsBN 8070839511, 2005.

[5] J. Halko. S. Pavlenko. Design strenght calculation of cycloidal lantern gear. In: BarSU Herald Scientific and practical journal, Physical and Mathematical Sciences, Engineering Sciences, No. 1 (2013), p. 58-65. - ISSN 2309-1339, 2013.

[6] M. Byrtus. Modeling of gearboxes with time dependent meshing stiffness. In Zeszyty naukowe Katedry Mechaniki Stosowanej, zeszyt nr 21, Proceedings of the conference. Applied Mechanics, Jaworzynka, Poland. 2003 pp. 35 - 30. ISBN 83-917224-3-0, 2003.

[7] X. L., S. Liu, Y. Wang. Design and Analysis of a Stator HTS Field - Modulated Machine for Direct 
Drive Applications. IEEE Transactions on Applied Superconductivity. Institute of Electrical and Electronics Engineers Inc. ISSN 105182232017, 2017.

[8] S. Xue, I. Howard. Dynamic Modelling of Flexibly Supported Gears Using Iterative Convergence of Tooth Mesh Stifness. Mechanical Systems and Signal Processing. Academic Press. ISSN 08882370, 2016.

[9] R. J. Boby, E. Raj Kumar. Design and Analysis of Gear Systém for Turobshaft Aero Engine Reduction Gearbox. International Journal of Mechanical Engineering and Technology. Indian Society for Education and Enviroment. ISSN 09746846, 2016.

[10] V. Balambica, T. J. Prabhu, R. V. Babu. Finite Element Application of Gear Tooth Analysis. Advanced Materials Research. 2013 4th International Conference on Advances in Materials and Manufacturing, ICAMMP 2013; Kunming; China Volume 889-890, 2014 Pages 527-531 ISSN 10226680, 2014.

[11] A. A. Umar, A. S. Ahmad, A. G. Yusuf, Z. I. Bibi Farouk. Effect of face width on bending stress of spur gear using AGMA and FEA. Advanced Materials Research. Volume 945-949, 2014, Pages 840-844. Trans Tech Publications Ltd. ISSN 10226680, 2016.

[12] X. Q. Sun, Y. Zhang, D. W. Shi. Dynamics simulation and fatigue life study of the drive system of rack and pinion climbing vertical ship lift. Applied Mechanics and Materials. 2014 International Conference on Manufacturing Technology and Electronics Applications, ICMTEA 2014; Taiyuan; ChinaVolume 687-691, 2014, Pages 93-96. ISSN 16609336, 2014. 